\title{
Comparisons of Different Types of Organic Manures Integrated in Diverse Ratios with Inorganic N Fertilizer in Terms of Maize Yield and Productivity
}

\author{
Mussaddiq Khan Khalil, ", Shuja Ur Rehman Qureshi ${ }^{2}$, Muhammad Owais Khan ${ }^{1}$, Mukhtiar Ali ${ }^{1}$, \\ Waqar Ali ${ }^{1}$, Muhammad Tariq ${ }^{1}$, Sultan Nawaz ${ }^{1}$ \\ ${ }^{1}$ Soil and Environmental Sciences, The University of Agriculture Peshawar, KPK, Pakistan \\ ${ }^{2}$ Plant Breeding and Genetics, The University of Agriculture Peshawar, KPK Pakistan
}

Email address:

mussaddiqses@gmail.com (M. K. Khalil)

${ }^{*}$ Corresponding author

\section{To cite this article:}

Mussaddiq Khan Khalil, Shuja Ur Rehman Qureshi, Muhammad Owais Khan, Mukhtiar Ali, Waqar Ali, Muhammad Tariq, Sultan Nawaz. Comparisons of Different Types of Organic Manures Integrated in Diverse Ratios with Inorganic N Fertilizer in Terms of Maize Yield and Productivity. Modern Chemistry. Vol. 8, No. 1, 2020, pp. 6-11. doi: 10.11648/j.mc.20200801.12

Received: September 19, 2019; Accepted: September 29, 2019; Published: April 1, 2020

\begin{abstract}
In modern agriculture the integration of organic and inorganic fertilizers has been proved as the best technique to maximize the nutrient availability to crops for longer period of time and to minimize the essential nutrients loss from rhizosphere soil. However, most of the researchers and farmers are uninformed of that which is the best fertilizer integration ratio and what type of organic manure should be used for obtaining good fertile soil and economical crop yield. In response of the above question the present research experiment was carried out in in kharif season 2018 at Cereal Crop Research Institute (CCRI), Nowshera, KPK, Pakistan to investigate the performance of maize crop in response to different types of organic manures integrated with inorganic nitrogen fertilizer in distinct ratios based on $\%$ nitrogen $(\mathrm{N})$. Total 9 treatments were used in the experiment such as $\mathrm{T} 1$ (Control $=100 \% \mathrm{~N}$ from Urea), $\mathrm{T} 2(50 \% \mathrm{~N}$ from $\mathrm{SSB}+50 \% \mathrm{~N}$ from Urea), $\mathrm{T} 3(50 \% \mathrm{~N}$ from $\mathrm{SCB}+50 \% \mathrm{~N}$ from Urea), $\mathrm{T} 4(50 \% \mathrm{~N}$ from $\mathrm{PL}+50 \% \mathrm{~N}$ from Urea), $\mathrm{T} 5(50 \% \mathrm{~N}$ from $\mathrm{FYM}+50 \% \mathrm{~N}$ from Urea), $\mathrm{T} 6(25 \% \mathrm{~N}$ from $\mathrm{SSB}+75 \% \mathrm{~N}$ from Urea), $\mathrm{T} 7(25 \% \mathrm{~N}$ from $\mathrm{SCB}+75 \% \mathrm{~N}$ from Urea), $\mathrm{T} 8(25 \% \mathrm{~N}$ from PL $+75 \% \mathrm{~N}$ from Urea) and $\mathrm{T} 9(25 \% \mathrm{~N}$ from FYM $+75 \% \mathrm{~N}$ from Urea). The outcomes of the experiment revealed that all the treatments have significantly affected the kernel yield, plant height, 100 kernel weight and ear length while the number of kernel rows was non-significant. Treatments having 1:1 combination (T2, T3, T4 and T5) has far more better results as compared to 3:1 ratio combination (T6, T7, T8 and $\mathrm{T} 9)$ and 1:0 ratio combination (T1). Among 1:1 treatment the overall performance of treatment $\mathrm{T} 2(50 \% \mathrm{~N}$ from soya bean straw biochar (SSB) $+50 \% \mathrm{~N}$ from urea) was best of all increasing the kernel yield, plant height, 100 kernel weight, ear length and kernel rows per cob up to $54.5 \%, 15.2 \%, 16 \%, 17.7 \%$ and $8.1 \%$ respectively more than any other treatment. Hence integration of soya bean straw biochar with urea in $1: 1$ based on $\% \mathrm{~N}$ is advised for maximum yield and better growth performance of maize. Such studies on different cereal and leguminous crops under different soil and climatic conditions is recommended for vast spread application and authorization of results.
\end{abstract}

Keywords: Maize, Soyabean Straw Biochar, Sugarcane Bagasse, Poultry Litter, Farmyard Manure, Urea, Kernel Yield

\section{Introduction}

Maize botanically called as Zea mays L. is the $3^{\text {rd }}$ most growing cereal crop in Pakistan after wheat and rice [1]. It is a nutritional source of food for humans, feed for animals and raw material for several agro-based industries. It belongs to the cereal crop family which require adequate amount of essential nutrients due to its ability high growth rate and producing large biomass yield [2]. Nature of Pakistani soils comes in category of alkaline calcareous soils in which maize crop suffers from nitrogen deficiency [3]. Various other factors which will affect the nitrogen availability is temperature, moisture content, $\mathrm{pH}$ of the soil and amount of clay minerals in the soil. Nitrogen is the most essential nutrient required for plant growth and is 
usually absorbed by plants in form of nitrate [4] and it constitutes about $1.7 \%$ to $5.8 \%$ of dry weight of many plants. It is the also the important component of many nucleic acids, organic acids and many proteinaceous compounds, apart from this its plays a vital role in synthesis of chlorophyll, photosynthesis process and carbon dioxide $\left(\mathrm{CO}_{2}\right)$ assimilation [5]. Nitrogen also have synergistic relation with other nutrients like phosphorous, potassium and calcium and deficiency of nitrogen in soil will result the plants to suffer from others nutrients deficiency [6]. The major loss of nitrogen in Pakistani soils occurs through leaching due to its mobile nature in soils. Integration of organic and inorganic is the best possible way to reduce nitrogen loss through leaching and to increase its availability to crops for longer period of time [7].

Nowadays the combine application of organic and inorganic fertilizers has been a favorable method for farmers to enhance their crop yield and production growth. [8] Investigated that significant influence of plant residues biochar on cereal crops when applied in combination with inorganic fertilizers $[9,10]$ also reported significant increase in maize yield when they are treated with integration of organic manure compost and mineral fertilizer in various ratios. However, most of the researchers and farmers are unaware of that which is the best fertilizer integration ratio and what type of organic manure should be used for obtaining good fertile soil and economical crop yield. The present study was planned to investigate the comparison between various types of organic manures for obtaining best performance of maize crop in terms of yield and productivity and to evaluate what is the best integration ratio between organic manures with inorganic nitrogen fertilizers for economical maize yield and various other yield attributes of maize crop in agro-climatic conditions of Nowshera, KPK, Pakistan.

\section{Materials and Methods}

The field experiment entitled as "Comparisons of different types of organic manures supplemented in diverse ratios with inorganic $\mathrm{N}$ fertilizer in terms of maize yield and productivity" was carried out at Cereal Crop Research Institute was carried out at Cereal Crop Research Institute (CCRI), Nowshera, KPK, Pakistan in kharif season 2018. Maize variety $(B S-01)$ is used as attest crop. Total 9 treatments were used and each treatment was replicated five times thus making 45 experimental units. Each of the plot size was $12 \mathrm{~m}^{2}(4 \mathrm{~m} \times 3 \mathrm{~m})$. The experimental units were designed according to Randomize Complete Block design. The treatment combination was shown in table 1 .

Table 1. Treatments combination of the present experiment.

\begin{tabular}{|c|c|c|c|c|}
\hline Treatments & $\% \mathrm{~N}$ from Organic manure (O. M) & $\% \mathrm{~N}$ from Urea & Urea: O. M (based on \%N) & Required amount of $N$ (kg/ha) \\
\hline T1 (Control) & 0 & $100 \%$ & $1: 0$ & 120 \\
\hline $\mathrm{T} 2$ & $50 \% \mathrm{~N}$ from SSB & $50 \%$ & $1: 1$ & 120 \\
\hline $\mathrm{T} 3$ & $50 \% \mathrm{~N}$ from $\mathrm{SCB}$ & $50 \%$ & $1: 1$ & 120 \\
\hline $\mathrm{T} 4$ & $50 \% \mathrm{~N}$ from $\mathrm{PL}$ & $50 \%$ & $1: 1$ & 120 \\
\hline T5 & $50 \% \mathrm{~N}$ from $\mathrm{FYM}$ & $50 \%$ & $1: 1$ & 120 \\
\hline T6 & $25 \% \mathrm{~N}$ from $\mathrm{SSB}$ & $75 \%$ & $3: 1$ & 120 \\
\hline $\mathrm{T} 7$ & $25 \% \mathrm{~N}$ from $\mathrm{SCB}$ & $75 \%$ & $3: 1$ & 120 \\
\hline T9 & $25 \% \mathrm{~N}$ from $\mathrm{FYM}$ & $75 \%$ & $3: 1$ & 120 \\
\hline
\end{tabular}

Abbreviations:

$\mathrm{N}=$ Nitrogen.

$\mathrm{SSB}=$ Soya bean straw biochar.

$\mathrm{SCB}=$ Sugar cane bagasse.

$\mathrm{PL}=$ Poultry Litter.

FYM=Farm yard Manure.

Basal dosage $90 \mathrm{~kg} / \mathrm{ha}$ and $60 \mathrm{~kg} / \mathrm{ha}$ of phosphorous and potassium respectively was applied to each plot prior to one week before the sowing. Different types of organic manures were also applied to specified plots before one week of sowing whereas urea was applied in split doses at time of sowing and fist irrigation. The composite soil sample was collected from field before the initiation of the experiment and was processed and analyzed for Soil texture by method of [11], $\mathrm{pH}$ of soil by method of [12], electrical conductivity (EC) by method proposed by [13], Organic matter content by method of [14], total nitrogen by method of [15], Extractable phosphorous and potassium by method proposed by [16], in the laboratory in order to evaluate the physical and chemical properties of the experimental location and its data is shown in the table 2. It shows that the soil was slightly alkaline, non-saline, silty loam in texture and was deficient in organic matter, total nitrogen, extractable phosphorous and potassium. The samples were also taken from various types of organic manures used in the experiment and was analyzed for different chemical properties and its data is shown in table 3 .

Table 2. Physical and chemical properties of experimental site.

\begin{tabular}{ll}
\hline Physical and Chemical Property & Value and Unit \\
\hline Soil Texture & Silty Loam \\
$\mathrm{pH}$ & 7.75 \\
Electrical conductivity & $2.17 \mathrm{dSm}^{-1}$ \\
Organic matter & $0.81 \%$ \\
Bulk density & $1.23 \%$ \\
Total Nitrogen & $0.46 \%$ \\
Extractable Phosphorous & $3.73 \mathrm{~kg} / \mathrm{ha}$ \\
Extractable Potassium & $91.65 \mathrm{~kg} / \mathrm{ha}$ \\
\hline
\end{tabular}


Table 3. Chemical Properties of different types of organic manures used in the experiment.

\begin{tabular}{|c|c|c|c|c|}
\hline \multirow{2}{*}{ Chemical Property } & \multicolumn{4}{|c|}{ Different types of organic manures } \\
\hline & SSB & SCB & PL & FYM \\
\hline $\mathrm{pH}$ & 7.90 & 7.68 & 7.60 & 7.20 \\
\hline Electrical conductivity $\left(\mathrm{dsm}^{-1}\right)$ & 2.86 & 3.11 & 3.08 & 2.66 \\
\hline Organic carbon $(\%)$ & 43.7 & 28.3 & 35.1 & 28.9 \\
\hline $\mathrm{CN}$ ratio & 29.3 & 25.7 & 22.2 & 32.6 \\
\hline Total Nitrogen $(\%)$ & 1.14 & 1.10 & 1.58 & 0.86 \\
\hline Total Phosphorous (\%) & 0.74 & 0.70 & 2.12 & 1.14 \\
\hline Total Potassium (\%) & 1.58 & 1.48 & 1.34 & 1.20 \\
\hline
\end{tabular}

The data of the following parameters are recorded during the experiment:

1. Plant height $(\mathrm{cm})$.

2. Ear length $(\mathrm{cm})$.

3. Number of rows of kernel per each cob.

4. Weight of hundred kernels (g).

5. Kernel Yield (kg/ha).

\subsection{Plant Height (cm)}

The data of the plant height of the maize was calculated at full maturity phase of the crop. From each experimental unit, ten random plants were selected and their heights were measured in centimeters with the help of graduated scale with one end of scale at ground and the other end at auricle of the flag leaf. After that average of the calculated data was taken.

\subsection{Ear Length (cm)}

Data of length of the ear is also calculated with help of graduated scale. From each experimental unit, ten random plants were selected and their ear lengths were measured in centimeters with one end of the graduated scale at ground and the other end at node having the uppermost primary ear. After that average of the calculated data was taken.

\subsection{Number of Rows of Kernel Per Each Cob}

Data of kernel rows per ear is calculated by randomly taking ten cobs from each plot and the grain rows each cob was counted and then its mean was taken.

\subsection{Weight of Hundred Kernels (g)}

Data of hundred kernels weight is measured in grams with help of electric balance. 100 kernels were counted from various cobs of each experimental unit and their weight is measured in grams with sensitive electric balance.

\subsection{Kernel Yield $(\mathrm{kg} / \mathrm{ha})$}

Data of grain or kernel yield is calculated by harvesting five central rows of each plot. The cobs were shredded and their grains were collected and was measured in kilograms with help of electric balance. The final grain yield in kilograms per hectares is calculated by following formula;

$$
\text { Kernal yield }\left(\mathrm{kg} \mathrm{ha}^{-1}\right)=\frac{\text { Yield of Kernels per rows }}{\mathrm{R}-\mathrm{R} \operatorname{space}(\mathrm{m}) \times \text { row size }(\mathrm{m}) \times \text { No. of rows }} \times 10,000 \mathrm{~m}^{2}
$$

\section{Statistical Analysis:}

ANOVA (analysis of variance) procedures appropriate for RCB design was used for statistical analysis of the data. Least significance difference (LSD) test at 0.05 probability level were used to compare the means, when the F-values were significant [17]. The data was then also analyzed by computer software program STATISTIX 10.1.

\section{Results and Discussion}

\subsection{Results}

Mean values of plant height, ear length, number of kernels rows per cob, weight of 100 maize kernels and kernel yield in table 4 shows that various types of organic manures supplemented with urea in dynamic ratios has significantly affected the kernel yield and various yield attributes of maize except number of kernel rows per each cob which is nonsignificant. In case of plant height, maximum plant height $(170.1 \mathrm{~cm})$ was examined for T2 receiving soya bean straw biochar (SSB)+urea in 1:1 ratio significantly tailed by
$(168.2 \mathrm{~cm})$ given by $\mathrm{T} 3$ receiving $1: 1$ ratio of sugarcane bagasse (SCB)+Urea. While the minimum plant height of $147.7 \mathrm{~cm}$ was recorded for $\mathrm{T} 1$ treatment control receiving only $100 \%$ urea. The same phenomenon is reflected in figure 1 which shows that treatment T2 (Urea + SSB applied in 1:1 ratio) has increased the plant height up to $15.2 \%$ followed by treatment T3 (Urea + SCB applied in 1:1 ratio) which has increased the plant height up to $13.9 \%$ over control treatment. In case of ear length parameter maximum value $(22.4 \mathrm{~cm})$ was calculated for T4 receiving $1: 1$ ratio of poultry litter (PL) and urea successfully followed by results $(21.6 \mathrm{~cm})$ from $\mathrm{T} 2$ receiving $\mathrm{SSB}+$ urea in $1: 1$ While the minimum ear length of 18.1 was recorded for $\mathrm{T} 1$ treatment control receiving only $100 \%$ urea. In case of number of kernel rows per cob, maximum kernel rows (16.0) was investigated for T2 receiving SSB + urea in 1:1 significantly tailed by (15.7) given by $\mathrm{T} 4$ receiving $1: 1$ (PL + Urea). While the kernel rows of 14.8 was recorded for $\mathrm{T} 1$ treatment control receiving only $100 \%$ urea. However, the number rows of kernel were not significantly affected by combination of urea with different organic manures in diverse ratios. 
Weight of hundred maize kernels was significantly influenced by different treatments used in the experiment. Maximum values (41.1g) are obtained for treatment $\mathrm{T} 2$ getting $50 \% \mathrm{~N}$ from $\mathrm{SSB}+50 \% \mathrm{~N}$ from urea, significantly tailed by $(39.7 \mathrm{~g})$ treatment $\mathrm{T} 6$ receiving $25 \% \mathrm{~N}$ from $\mathrm{SSB}+75 \% \mathrm{~N}$ from urea (applied in 1:3), while minimum 100 kernel weight of 35.9 (35.9g) was obtained from $\mathrm{T} 1$ control treatment. Similarly, the like plant height and 100 kernel weight, the maximum kernel yield $(5123.7 \mathrm{~kg} / \mathrm{ha})$ was examined for treatment $\mathrm{T} 2$ receiving $50 \% \mathrm{~N}$ from $\mathrm{SSB}+50 \% \mathrm{~N}$ from urea $(1: 1)$, significantly followed kernel yield $(4928.9 \mathrm{~kg} / \mathrm{ha})$ given by treatment $\mathrm{T} 4$ receiving $50 \% \mathrm{~N}$ from $\mathrm{PL}+50 \% \mathrm{~N}$ whereas minimum kernel yield $(3315.6 \mathrm{~kg} / \mathrm{ha})$ was recoded for $\mathrm{T} 1$ control treatment receiving $100 \% \mathrm{~N}$ from Urea (1:0). The same phenomenon is also represented in figure 2 which shows that treatment T2 (Urea + SSB applied in 1:1 ratio) has increased the kernel yield ( $\mathrm{kg} / \mathrm{ha}$ ) up to $54.5 \%$ followed by treatment $\mathrm{T} 4$ (Urea + PL applied in 1:1 ratio) which has increased the kernel yield up to $48.7 \%$ over control treatment T1 gaining alone urea.

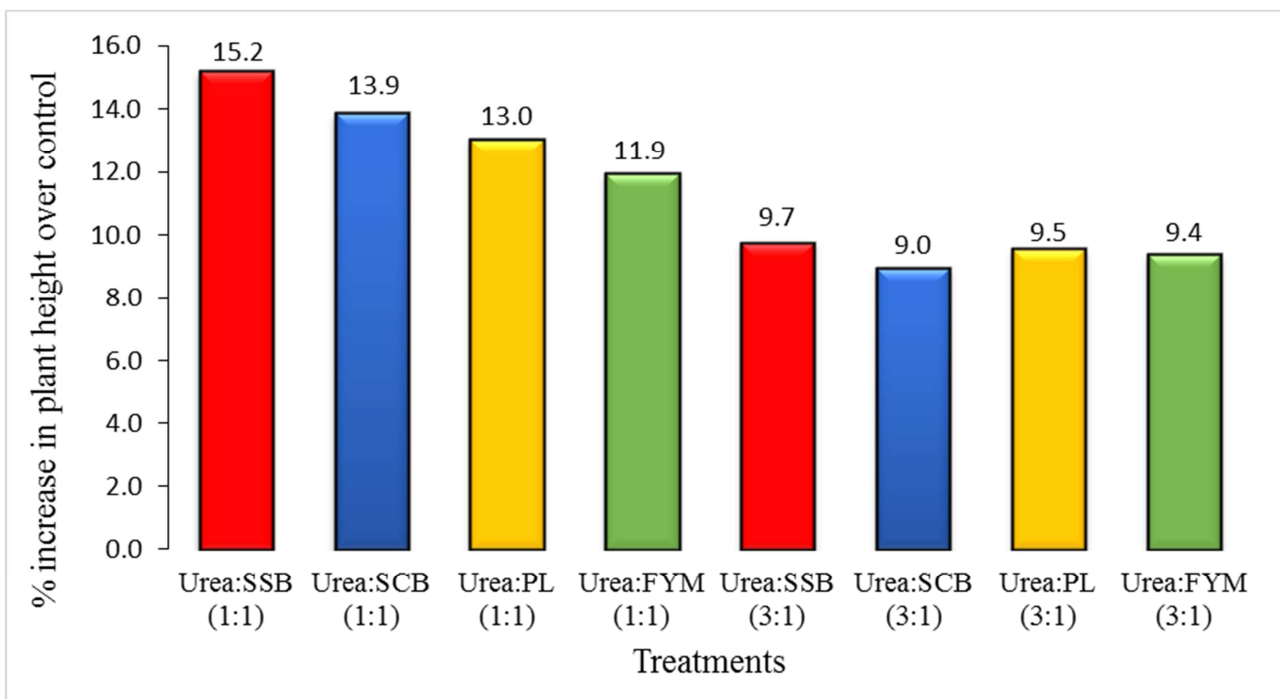

Figure 1. Percent increase in plant height of maize by treatments having various organic manures and inorganic fertilizers integrated in different ratios.

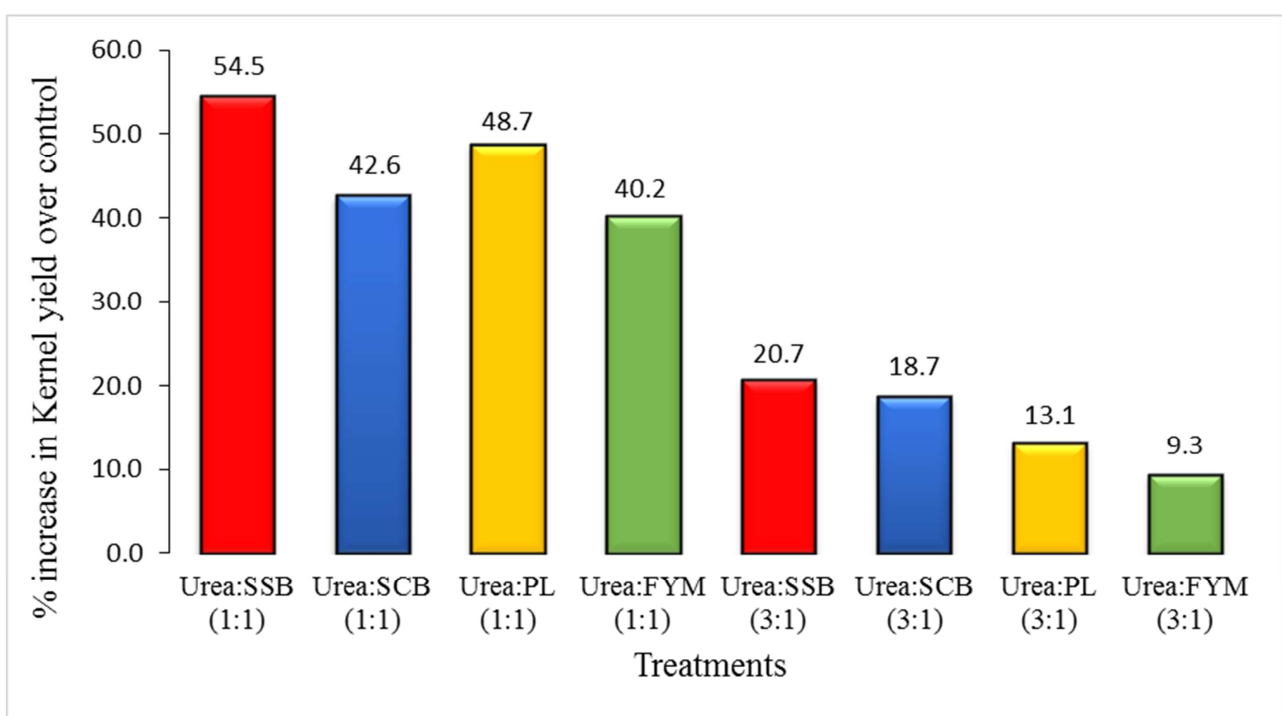

Figure 2. Percent increase in kernel yield of maize by treatments having various organic manures and inorganic fertilizers integrated in different ratios.

\subsection{Discussion}

By comparing the results of kernel yield and various yield traits of maize significantly affected by organic manures applied to the field in distinct ratios with urea. The treatments having 1:1 combination (T2, T3, T4 and T5) has far more better results as compared to $3: 1$ ratio combination (T6, T7, $\mathrm{T} 8$ and T9) and 1:0 ratio combination (T1). Among 1:1 treatment the overall performance of treatment $\mathrm{T} 2(50 \% \mathrm{~N}$ from soya bean straw biochar (SSB) $+50 \% \mathrm{~N}$ from urea) was best increasing the kernel yield up to $54.5 \%$ more than any other treatment. The above data is strongly corelated with the findings of [8] who suggested that combine application of inorganic fertilizers and soya bean straw biochar will significantly influence the production of cereal crops. 
Presumably it may be due to better mineralization of nitrogen and other nutrients offered by soya bean straw biochar. Due to enhanced microbial activity, plant residues biochar plays a vital role in enhancing the solubilization of nutrients present in the soil and manures by releasing different types of organic acids such as formic, carbonic and citric acids during decomposition process [18], resulting into increasing essential nutrients availability to plants and reducing its losses from rhizosphere $[19,20]$. The function of biochar is that it immobilizes the nutrients by chelation process and then slowly released the nutrients to the plant in different growth phases. The synergistic relation nitrogen with phosphorous and other nutrients [6] plays a vital role in its uptake resulting into vigorous roots, shoots and healthy grains development. Due to mobile nature of nitrogen, it moves to the grains after its uptake resulting it to enhanced kernel weight and yield. The above results lie in par with [21, 22] who reported that combination of biochar with inorganic fertilizers had a significant effect on maize yield and development. [23, 24] also received positive response from plant yield when they applied organic manures in combination with inorganic fertilizers.

Table 4. Plant height, ear length, rows of kernel cob $^{-1}$, hundred kernel weight and kernel yield as affected by treatments having various organic manures and inorganic fertilizers integrated in different ratios.

\begin{tabular}{|c|c|c|c|c|c|}
\hline \multirow{2}{*}{ Treatments } & Plant height & Ear length & Rows of kernel $\operatorname{cob}^{-1}$ & Hundred seed weight & Kernel Yield \\
\hline & $(\mathbf{c m})$ & $(\mathbf{c m})$ & - & (g) & (kg/ha) \\
\hline $\mathrm{T} 1=$ Control $(100 \% \mathrm{~N}$ from Urea $)$ & $147.7 \mathrm{e}$ & $18.1 \mathrm{~d}$ & 14.8 & $35.9 \mathrm{~d}$ & $3315.6 \mathrm{f}$ \\
\hline $\mathrm{T} 2=50 \% \mathrm{~N}$ from $\mathrm{SSB}+50 \% \mathrm{~N}$ from Urea & $170.1 \mathrm{a}$ & $21.6 \mathrm{ab}$ & 16.0 & $41.1 \mathrm{a}$ & $5123.7 \mathrm{a}$ \\
\hline $\mathrm{T} 3=50 \% \mathrm{~N}$ from $\mathrm{SCB}+50 \% \mathrm{~N}$ from Urea & $168.2 \mathrm{ab}$ & $20.4 b$ & 15.3 & $40.0 \mathrm{ab}$ & $4728.3 b$ \\
\hline $\mathrm{T} 4=50 \% \mathrm{~N}$ from $\mathrm{PL}+50 \% \mathrm{~N}$ from Urea & $167.0 \mathrm{ab}$ & $22.4 \mathrm{a}$ & 15.7 & $39.0 \mathrm{bc}$ & $4928.9 \mathrm{ab}$ \\
\hline $\mathrm{T} 5=50 \% \mathrm{~N}$ from $\mathrm{FYM}+50 \% \mathrm{~N}$ from Urea & $165.3 b$ & $20.8 b$ & 15.0 & 38.7 & $4648.0 \mathrm{bc}$ \\
\hline $\mathrm{T} 6=25 \% \mathrm{~N}$ from $\mathrm{SSB}+75 \% \mathrm{~N}$ from Urea & $162.1 \mathrm{bc}$ & $21.1 \mathrm{ab}$ & 14.9 & $39.7 \mathrm{abc}$ & $4002.7 \mathrm{c}$ \\
\hline $\mathrm{T} 8=25 \% \mathrm{~N}$ from $\mathrm{PL}+75 \% \mathrm{~N}$ from Urea & $161.8 \mathrm{~cd}$ & $19.5 \mathrm{bc}$ & 15.2 & $38.3 \mathrm{c}$ & $3749.0 \mathrm{cde}$ \\
\hline $\mathrm{T} 9=25 \% \mathrm{~N}$ from $\mathrm{FYM}+75 \% \mathrm{~N}$ from Urea & $161.5 \mathrm{~cd}$ & $19.0 \mathrm{bc}$ & 14.8 & $36.6 \mathrm{~cd}$ & $3625.3 \mathrm{de}$ \\
\hline LSD & $4.57 * * *$ & $1.48 *$ & $1.41 \mathrm{NS}$ & $2.77 *$ & $387.56 * * *$ \\
\hline
\end{tabular}

NS (Non-significant) if $\mathrm{P}>0.05 ; *$ if $\mathrm{P} \leq 0.05 ; * *$ if $\mathrm{P} \leq 0.01 ; * * *$ if $\mathrm{P} \leq 0.001$

Abbreviations:

$\mathrm{SSB}=$ Soya bean straw biochar.

$\mathrm{SCB}=$ Sugar cane bagasse.

$\mathrm{PL}=$ Poultry Litter.

FYM=Farm yard Manure.

LSD $=$ Least Significant Difference.

\section{Conclusions}

From the present study it is concluded that all the treatments receiving integration of organic and inorganic fertilizers in diverse ratios have significantly affected the kernel yield, plant height, 100 kernel weight and ear length while the number of kernel rows was non-significant. Maximum values of plant height $(170 \mathrm{~cm}), 100$ kernel weight (41.1g), kernel rows per cob (16.0) and kernel yield $(5123.7 \mathrm{~kg} / \mathrm{ha})$ was given by treatment T2 [soya bean straw biochar (SSB)+urea applied in 1:1) whereas maximum value for ear length (was obtained from treatment T4 (poultry litter PL + Urea applied in 1:1).

Treatments having 1:1 combination has far more better results as compared to 3:1 ratio and control. Among 1:1 treatment the overall performance of treatment $\mathrm{T} 2(50 \% \mathrm{~N}$ from soya bean straw biochar (SSB) $+50 \% \mathrm{~N}$ from urea) was best of all increasing the kernel yield, plant height, 100 kernel weight, ear length and kernel rows per cob up to $54.5 \%, 15.2 \%, 16 \%, 17.7 \%$ and $8.1 \%$ respectively more than any other treatment. Hence integration of soya bean straw biochar with urea in 1:1 based on $\% \mathrm{~N}$ is recommended for maximum yield and better growth performance of maize grown under agro climatic conditions of District Nowshera, Pakistan.

\section{References}

[1] MNFSR. 2014. Agricuture statistics of Pakistan. Ministry of National Food Security and Research, Islamabad, Pakistan.

[2] Mengel, K. and E. A. Kirkby. 2001. Principles of Plant Nutrition. 5th ed., Kluwer Academic Publishers, London.

[3] NFDC. 2001. Balanced fertilization through phosphate promotion. Project terminal report. NFDC, Islamabad, Pakistan.

[4] Tisdale SL, Nelson WL. 1990. Soil fertilizer and effect of magnesium on the yield and chemical of crops. Michigan Agricultural Experimental Statistics. Bull Press, Mechigan, American, p 29-31.

[5] Jasso-Chaverria C, Hochmuth GJ, Hochmuth RC, Sargent SA. 2005. Fruit yield, size, and colour responses of two Greenhouse cucumber types to nitrogen fertilization in perlite soilless culture. Horticulture Technology. 15: 565.

[6] Brady C. 1984. The nature and properties of soils. Macmillan Publishing Company, New York.

[7] Whalen, J. K. and C. Chang. 2001. Phosphorus accumulation in cultivated soils from long-term annual applications of cattle feedlot manure. Journal of Environmental Quality 30: 229237. 
[8] Maha M. E. Ali. 2018. Effect of Plant Residues Derived Biochar on Fertility of a new Reclaimed Sandy Soil and Growth of Wheat (Triticum aestivum L.) Egypt. J. Soil Science 58 (1): 93-103.

[9] Ditta, A., J. Muhammad., M. Imtiaz., S. Mehood., Z. Qian and S. Tu. 2018. Application of rock phosphate enriched compost increases nodulation, growth and yield of chickpea. International Journal of Recycling of organic waste in Agriculture. 7: 33-40.

[10] Ali W., M. Ali., A. Kamal., M. Uzair., N. Ullah and M K Khalil. 2019. Maize Yield Response under Various Phosphorus Sources and their Ratios European Journal of Experimental Biology. 9 1: 5.

[11] Gee, G. W and J. W. Bauder. 1986. Particle-size Analysis. In: Klute, A. (Ed.) Methods of soil analysis. Physical and Mineralogical methods. Agronomy monograph 9 (2ed). Amer. Soc. Agron. Madison. pp 383-411.

[12] Mclean, E. O. 1982. Soil pH and Lime Requirement. In: Page, A. L., Ed., Methods of Soil Analysis. Part 2. Chemical and Microbiological Properties, American Society of Agronomy, Soil Science Society of America, Madison, 199-224.

[13] Black, C. A. 1965. Methods of Soil Analysis: Part I, Physical and Mineralogical Properties. American Society of Agronomy, Madison, Wisconsin.

[14] Nelson, D. W and I. E. Sommer. 1982. Total carbon, Organic carbon and organic matter. pp. 539-577: In: A. L. page, R. H. Miller and D. R. Keeny, (ed.) Methods of soil analysis part 2 2nd ed. Am. Soc. Agron. Madison, Wisconsin.

[15] Bremner, J. M. and C. S. Mulvaney 1982 Total nitrogen Methods of Soil Analysis, Part 2, Chemical and microbiological properties American Society of Agronomy and Soil Science Society of America, Madison, pp. 11191123 .

[16] Soltanpur, P. N., and A. P Schwab. 1997. A new soil test from simultaneous extraction of macro and micro nutrients in alkaline soils. Comm. Soil. Sci. Plant analysis. 8: 195-207.

[17] Jan, M. T., P. Shah, P. A. Hollington, M. J. Khan and Q. Sohail. 2009. Agriculture Research: Design and Analysis. Dept. of Agronomy, KPK Agric. Uni. Peshawar, Pakistan.

[18] Kapoor K. K., Mishra M. M., Kukreja K. (1989): Phosphate solubilization by soil microorganisms. A review. Indian $\mathrm{J}$. Microbiol., 29: 119-127.

[19] Biederman L A and W. Stanley Harpole. 2012. Biochar and its effects on plant productivity and nutrient cycling: a metaanalysis. Global Change Biology Bioenergy. Volume 5, Issue 2, Special Issue: Biochar. 202-214.

[20] Kamal, M. 2014. Effect of biochar prepared from popular tree leaves on some microbiological properties of soil. In: F. Rasul and S. Shackley, eds., Proceedings of an International Workshop on Biochar in Pakistan: Biochar for climatefriendly agriculture shifting paradigms towards higher precision and efficiencies, held at the University of Agriculture, Faisalabad. 7: 24-27.

[21] Zhang A, Liu Y, Pan G, Hussain Q, Li L, Zheng J, Zhang X. 2012. Effect of biochar amendment on maize yield and greenhouse gas emissions from a soil organic carbon poor calcareous loamy soil from Central China Plain, Plant Soil. 351: 263-275.

[22] Srđan I. Šeremeši, Milorad S. Živanov, Dragiša S. Milošev, Jovica R. VASIN, Vladimir I. ĆIRIĆ, Marjana B. Vasiljević, Nataša J. Vujić. 2015. Effects of biochar application on morphological traits in maize and soybean. J. Nat. Sci. Novi Sad, №. 129: 17-25.

[23] Jamal, K., M. Nawaz., M. Shah and J. K. Khattak. 1989. Effect of pretreated farmyard manure (FYM) with phosphatic fertilizers on yield of wheat. Pakistan Journal of Agricultural Research. 10 (4): 315-322.

[24] Udom GN and Bello HM. 2009. Effect of poultry litter on the yield of two maize varieties in the northern gulnea savanna. J Trop Agric Food Environ Exten 8: 51-54. 